\title{
PERCEIVED ORGANIZATIONAL FACTOR, INTERNAL MARKETING AND ORGANIZATIONAL COMMITMENT IN UNIVERSITY TEACHERS
}

\author{
FATOR ORGANIZACIONAL PERCEBIDO, MARKETING INTERNO E COMPROMETIMENTO \\ ORGANIZACIONAL EM PROFESSORES UNIVERSITÁRIOS
}

Recebido em 10.03.2019. Aprovado em 02.05.2019 Avaliado pelo sistema double blind review DOI: https://doi.org/10.12712/rpca.v13i2.28209

\author{
Suzete Antonieta Lizote \\ lizote@univali.br \\ Programa de Pós-Graduação em Administração / Univali - Biguaçu/SC, Brasil \\ https://orcid.org/0000-0003-3575-1675
}

\section{Cláudia Silva Ribeiro Alves}

dinha.crsa@gmail.com

Programa de Pós-Graduação em Administração / Univali - Biguaçu/SC, Brasil

https://orcid.org/0000-0001-5257-4389

\section{Cledinei Clóvis Cavalheiro}

clovis.cavalheiro@gmail.com

Programa de Pós-Graduação em Administração / Univali - Biguaçu/SC, Brasil

https://orcid.org/0000-0001-7249-8117

\begin{abstract}
This examine the relationship between the organizational basis and the internal marketing with the commitment of university teachers. On this account, we used the factorial analysis, a new analysis of correlations. The results show the support of the direction and the reward, including positive correlation with the affective and normative components. However, the instruments have a negative correlation with freedom and work. Among the aspects of marketing, only the development showed a positive relationship with the normative components. Nevertheless, by turning into segments those who answered according to those who are to be considered in view of the institution, the relationships are being modified. Among five groups under consideration, in three, the aspects of marketing had positive correlations with the affective and normative components.
\end{abstract}

Keywords: Internal marketing. Commitment. Teachers.

\section{Resumo}

Neste estudo se examina a relação do suporte organizacional e marketing interno com o comprometimento dos docentes universitários. Para tanto, foram usadas análise fatorial, Anova e análise de correlações. Os resultados mostram apoio da direção e recompensas tendo correlação positiva com os componentes afetivo e normativo. Entanto o instrumental teve correlação negativa com liberdade no trabalho. Dos aspectos do marketing, apenas desenvolvimento apresentou relação positiva com o componente normativo. Contudo, segmentando os respondentes segundo imaginam serem considerados pela instituição, modificam-se os relacionamentos. Dos cinco grupos reconhecidos, em três os aspectos do marketing tiveram correlações positivas com os componentes afetivo e normativo.

Palavras-chave: Marketing interno. Comprometimento. Professores. 


\section{Introdução}

In today's knowledge society, the human factor has special significance for the whole company, whether due to the knowledge that employees have, or due to their relationship with their work and with the organization. It is the responsibility of managers to form teams of committed people, with the capacity to see and pursue opportunities; people that have or can develop their skills in the organization, and who will contribute to achieving the desired performance. Thus, given that human capital is increasingly considered a vital resource, and in the case of Higher Education Institutions (HEIs), whose basic raw material is intelligence, people are both the raw material and the instrument of intellectual production. The management model of these institutions, in general, is classified as complex (ANDRADE, 2002) and, to achieve satisfactory quality indicators, it requires individual skills, behaviors, and techniques.

To understand the complexity of university management, Andrade (2006) emphasizes that we should consider factors such as the high degree of autonomy of teachers, the dependence of individual skills, planning, diversity, and clarity of objectives, among other aspects. Focusing on universities in the Brazilian context, Bertucci (1999) concludes that decision-makers, at all levels, act as intermediaries between the environment and the organization, and its performance is directly influenced by how the managers perceive and understand the institution, how they begin, articulate and manage the decisionmaking processes in organizational units, and how they encourage their employees.

The HEIs, which are also impacted by changes in other types of organizations, are undergoing transformations that, according to Andrade (2006), demand better results and lower administrative and operational costs, which will enable the training of professionals qualified to work in the job market. These changes mean people must be encouraged to carry out their activities with job satisfaction, developing a spirit of creativity and teamwork, while respecting the autonomy and individuality of each one, to develop a work of excellence. Employees need to be motivated and committed, as they are being called upon to perform activities outside the traditional ones. As stated by Hashimoto (2006), today's scenario is marked by innovation.

In the last two decades in Brazil, following the promulgation of Law No. 9394/96 which established the guidelines and bases of national education, there was a significant increase in the number of HEIs and undergraduate courses (MUNIZ, 2006). As a result, there is greater competition between institutions, and this has led them to strive for higher levels of efficiency in their management, with the fundamental goal of satisfying their students and meeting the needs of the job market for graduates. Thus, considering that businesses demand higher levels of knowledge among job applicants, there has been an adaptation of undergraduate courses, with better definition of the professional and graphic profiles, and the promotion of active learning, seeking to give students a competitive advantage that would enable them to rapidly enter professional practice (LIZOTE, 2013). Under the current conditions, in an environment of uncertainty and high levels of competition, organizations seeking to be sustainable and retain their competitive advantage must have competent, creative and committed professionals (HARRIS; CAME, 2005).

In recent years, various studies have used Meyer and Allen's (1991) multidimensional model of organizational commitment, which was validated in Brazil by Medeiros and Enders (1998). Meyer and Allen's model of three components: affective, normative and continuance, as well as with some variants, have been applied to teachers working in Brazilian HEIs in several studies postgraduate course conclusion works, including those of Amaral (2008), Brandão (1991), Chaves (2011), Vital (2002), Sanches (2004), Giacomassa (2013) and Lizote (2013).

Affective commitment, according to several studies, is positively correlated with performance, since employees that have affective connections feel motivated and tend to make a more positively contribution to the organization (REGO; SOUTO, 2004). Similarly, normatively committed employees, 
as they carry out their activities, have a positive association with performance, depending, among other things, on their beliefs and values (NAMASIVAYAM; ZHAO, 2007) and this is also correlated with lower turnover and absenteeism rates (REGO; SOUTO, 2004). In organizations, employees who are continuance committed do not leave their jobs simply because that they have no options that are financially the same or better. From this perspective, as Powell and Meyer (2004) deduct, they see employment primarily as a source of income. This type of commitment is associated with poor performance, or with doing only minimum required for their job (REGO; CUNHA; SOUTO, 2007).

The studies of organizational commitment where occur frequent restructures in the environments, as for instance in the universities, they are important, because in accordance with Zanini, Santos end Lima (2018), the commitment of the collaborator is of fundamental importance in this context. For Silva and Andrade (2019) the aim to obtain and reach the objectives passes through organizational commitment of the members of the organization.

In view of these considerations, it is interesting to see how HEIs promote organizational behavior among their teachers. This study therefore chooses two strands for analysis and comparison. On one hand, it also considers the five stable factors recognized by Hornsby, Kuratko and Zahra (2002) in organizations that stimulate cooperative entrepreneurial conduct: managerial support, freedom at work, rewards, available time and uncertainties at work. On the other, it examines aspects of internal marketing according to the model used by Bohnenberger (2005) in Brazil, contemplating: development, admission and responsibilities, suitability for functions, internal communication and external communication. It seeks to assess the effects of managerial actions and communication in the perception of the collaborator, and how this relates to the components of behavior.

In this study, the purpose proposed was the analysis of a proximate mode of the complexity in which the universities operate, organizing a study of the configuration of institutions of the public and private regime, showing forth its relevance and the subsidy for understanding the relationships which occur in structures herein considered. From this perspective it is possible to distinguish two types of contributions: theoretical and empirical. This means, in the first perspective, that the results found in this research tend to give support for the understanding of the theoretical support of the structure. In the second one, an evaluation of this study has a practical support for the improvement for maintaining a university, with the purpose to increase or maintain the indicators of the performance. Consequently, the aim of this study is a subsidy for the institutions which wish to review, analyze or restructure its capacities of maintaining human resources.

\section{Organizational commitment}

Organizations are facing an accelerated and unique process of changes in their structure, forms of work organization, and in particular, styles of managing the social relations within them. For Bastos and Borges-Andrade (2002) the new productive processes require employees to be more participatory and independent, with the ability to work as a team and above all, committed to the results of the organization to which they belong. These processes, which are recognized as a challenge for the field of study of organizational commitment, involve changes in technology, global competition and consumer demand that are pressurizing companies to improve their efficiency (MEYER, 2009).

Understanding job commitment is of interest to professionals responsible for the formulation and implementation of management policies, and therefore requires a different practice in the area of human resources. In other words, it is necessary to act in a strategic way, and not just in an operational way (GILTS, 2000). According to Harris and Cameron (2005), in a constantly-changing and highly competitive environment, the organization, if it is concerned about survival, needs to attract and retain competent, creative and committed professionals. 
Organizational commitment has been studied in depth in recent decades, and its main focus is to find results that explain the level of commitment of the individual at work (BECKER; KLEIN; MEYER, 2009). Bastos (1994), Medeiros (1997) and Bandeira, Marques and Veiga (2000) emphasize that research in this area has been conducted using different approaches.

The empirical study of organizational commitment to be developed in this article will be based on the model of Meyer and Allen (1991). Which was validated in Brazil by Medeiros and Enders (1998) and Bandeira, Marques and Veiga (2000), bringing significant contributions to the study of multidimensionality. The proposers of the model argue that remaining in an organization can stem for desire, need and/or a sense of duty or obligation. Commitment is therefore analyzed from three fundamental dimensions: affective, continuance and normative.

The affective dimension, in dynamic form, originates in the organizational scenario when the employee has assimilated the values of the company, based on identification with their goals. This fact enhances the employee's involvement in their work, improving their performance, with the aim of facilitating the process of the organization, and encouraging them to continue working for the company (MEYER; ALLEN, 1991). From the same perspective, the individual takes a positive and active attitude towards the job and the company, i.e. he remains in the institution because he wants to (IVERSON; BUTTIGIEG, 1999), thus, commitment is understood as an emotional connection, a feeling, an impulse or desire that prompts him to stay (GONZALEZ; GUILLÉN, 2008).

The behavioral consequences arising from the affective focus correspond to extremely positive and strategic results for the organization that seeks to gain competitive advantage. As Meyer, Allen and Topolnytsky (1998) state, individuals with a strong affective commitment will tend to behave in a way that promotes the best interests of the organization. For Rego and Souto (2004), employees who are affectively committed are more likely to feel motivated to make a greater contribution to the organization, and it is associated with lower turnover, lower absenteeism, higher performance and higher organizational citizenship behaviors. Bonavides, Oliveira and Medeiros (2006) also state that an individual with affective commitment is more satisfied with their salary, the working conditions in the organization, the rewards, job recognition, the promotions received, the trust placed in them by their superiors, and the freedom they have.

The basis of the continuance link, unlike the other two dimensions, emphasizes an evaluation of the costs associated with leaving, and therefore involves a calculation of the gains and losses in the exchanges that the individual makes with the organization (MEYER and ALLEN, 1991). It is, therefore, a relationship based on an exchange between the company and the employee, the latter having a feeling that he needs to stay due to the amount of resources and time that he has already invested and would lose were he to leave (COMMEIRAS; FOURNIER, 2003).

Continuance commitment is seen in individuals who remain in the company based on the evaluation that they make, weighing the costs and rewards of staying or, the costs and risks of leaving the organization (CHANG, 2001). According to Chen and Francesco (2003), employees who are continuance committed stay in an organization because they do not have another job option that is financially as good as the present job. Another possibility, according to the authors, is that there are no alternatives on the job market. Thus, according to Rego and Souto (2004), they stay even though they do not want to, which could lead to passive or even negative attitudes.

From this perspective, the employee sees the company as a source of income, where there is an exchange between the labor and the financial reward (POWELL; MEYER, 2004). Rego, Cunha and Souto (2007) propose that calculatively committed employees will not perform far above the minimum required level, due to their feelings of dissatisfaction, injustice or even an inability to develop to their full potential. While affective commitment is related to less willingness to leave the organization, and the perception of 
being a member of the group, continuance commitment is negatively related to self-concept and perception of self-efficiency (HARRIS; CAMERON, 2005).

The normative component, in turn, sees commitment as a form of responsibility for the organization, and suggests that the individual remain in the company due to the personal sacrifice associated with leaving it (MEYER; HERSCOVITCH, 2001). Meyer and Allen (1997) suggest that employees tend to develop normative commitment when companies make certain investments that are difficult for them to compensate. This dimension may therefore be rooted in feelings of indebtedness of an individual to the organization, due to the benefits they have received (CHEN; FRANCESCO, 2003). According to Rego and Souto (2004), it is expected that normatively committed employees will make a positive contribution, through without the levels of involvement and enthusiasm seen in affectively committed employees.

This approach therefore presupposes that the individual's behavior is conducted in accordance with the set of normative pressures that the individual assumes internally; the individual accepts and believes that it is right and moral to do it. Bandeira, Marques and Veiga (2000) agree that normative organizational commitment presupposes that the individual's behavior is in accordance with the set of normative pressures that he assumes as internal. This form of bond establishes itself and is perpetuated through these normative pressures, internalized by the worker, and favorable to the interests and objectives of the managers of the organization.

\section{Organizational factors}

The employee's behavior at work is the result of several factors that influence how they respond. Identifying these factors, whether internal or external to the organization, and measuring how they are reflected in the behavior, it is important for understanding their commitment and motivation. In the case of higher education institutions, which are generally regarded as one of the main vectors of the socioeconomic and cultural development of countries, promoting the generation of intellectual capital, these aspects take on special significance. Among these institutions, universities, with their principal functions of teaching, research and extension activities, are the ones that represent a model and a reference, by reflecting aspects of the social reality. However, they must not only reflect the society, they also need to be prospective and protagonistic. And their teachers must be partakers and promoters of changes that will promote social advances. From this perspective, it is worth examining how the internal organizational factors are related to entrepreneurial corporate conduct, and with the involvement of university teachers, two personal behaviors that are linked to performance, and therefore to the quality of graduates.

An exploratory study on intra-entrepreneurial behavior carried out by Kuratko, Montagno and Hornsby (1990) uses five different constructs: support of senior management; rewards and resources available; structure and limits of the organization; propensity to risk; and availability of time. However, their empirical analyses led them to reduce these factors to: management support; organizational structure; and, resources and rewards available. Subsequently, Kuratko and Hodgetts (1998) demonstrate the main steps to creating a working environment that promotes intra-entrepreneural behavior among its employees: i) establishing explicit goals - these need to be mutually agreed upon by the staff and managers, so that specific steps can be achieved; (ii) creating a system of feedback and positive reinforcement - it is necessary for that potential intra-entrepreneurs or inventors to realize that there is acceptance and reward; (iii) emphasizing individual responsibility - trust and responsibility are key factors for the success of any program of innovation; and, (iv) providing rewards based on results - the system of rewards should highlight and encourage people to take risks and achieve.

The development of intra-entrepreneur behavior, according to Moriano et al. (2009), is favored or limited by the types of procedures that organizations determine of their employees in the performance of their activities. Hornsby, Kuratko and Zahra (2002) identify five organizational components that promote these conducts, namely: 
1) Managerial support - it is imperative that the managers accept employees who show intraentrepreneurial behavior, as well as enabling conditions and resources to develop innovative ideas; (JARILLO; STEVENSON, 1990). The management, according to Hisrich and Peters (2004), must facilitate the path for intra-entrepreneurs, enabling them to overcome bureaucratic barriers and/or obtain resources. According to Moriano et al. (2009), this is the extent to which the managerial structure encourages employees to believe that innovation and entrepreneurship are the role of everyone in the organization. They also argue that the conditions that reflect managerial support are: rapid adoption of the employees' ideas; recognition of people who can carry the ideas forward; support for small experimental projects; and, preselection of capital to initiate projects.

2) Freedom at work - consists in giving autonomy on the employees' decisions, delegating them authority and responsibility (ZAHRA; KORRI;YU, 2005). For Cozzi and Arruda (2004) this means the existence of values such as respect and trust in people; encouragement to act, and the decentralization of power. Siqueira and Gomide (2004) affirm that the autonomy given to employees prompts them to discover the best solutions for the business. Hashimoto (2006) is aware that the organizational system must be flexible enough to give freedom of decision-making and action for intra-entrepreneurs and their teams.

3) Rewards - encouraging employees to take on new challenges (KURATKO, MONTAGNO; HORNSBY, 1990; KURATKO, HORNSBY; BISHOP, 2005). According to the authors, to be effective they must be based on goals, feedback, individual responsibility, and rewards linked to results. For Stevenson and Jarillo (1990) in addition, there are challenges that increase the responsibility, the ideas of intra-entrepreneurial employees need to be known by the higher levels of the organizational hierarchy.

4) Time available - stimulates employees to have new ideas or develop new products, as well as amending existing procedures (HASHIMOTO et al., 2010).

5) Limitations or uncertainties in organizational tasks, as redefined in Moriano et al . (2009) - refers to the lack of clear standards and indecision on the level of performance expected of the employee. According to Kuratko, Hornsby and Bishop (2005), the management processes should be open, accessible to all and frequently reviewed, to ensure that the learning can be disseminated. For these authors, a lack of a strategic direction can inhibit actions that will really have an impact. Hashimoto (2006) argues that in an intra-entrepreneurial organization, the most form of communication is top-down communication, i.e. from the management to the other departments. It is in this direction that the chosen strategic direction, the details of the vision of the mission, the feedback generated from information received from the external environment, and the changes of institutional, originating internally, should flow.

Regarding the association between organizational factors and commitment, the importance of personnel management systems is highlighted, as a natural way of using human resources practices that favor commitment (MORROW; McELROY, 2001), although these should be used with caution (MEYER; HERSCOVITCH, 2001). A study by McElroy (2001) lists human resources practices and their possible impact on the affective, continuance and normative components of commitment.

In Brazil, Bastos and Lira (1997) carried out a study in a health institution, and concluded that organizational policies that value the worker bring positive support for commitment. Among them are rewards and recognition. The employee's perception of the recognition of their work by the organization promotes positive feelings and, consequently, commitment (GRANT, 2003).

It is widely recognized that effective human resources management contributes to organizational performance (SHEN; ZHU, 2011). Through these practices, we can better achieve the strategic goals of the organization, as well as meeting the individual needs of employees (SHEN, 2008). Su et al. (2009), in its turn, argue that contented people have a high degree of involvement with the organization and are more prone to make an effort, which leads to better organizational performance. Buck and Watson (2002) 
add that highly committed employees are more loyal, and more likely to stay with the companies where they work.

Many organizational leaders recognize that it is extremely important to examine how human resources, activities and programs are managed, both from the perspective of individuals and for the success of the organization (BUCK; WATSON 2002). Along these lines, Giauque et al. (2010) argue that it is currently accepted that the human resources management can help companies improve organizational behavior, such as teamwork, commitment, competence and flexibility, which in turn leads to corporate performance. Within higher education institutions, a study by Smeenk et al. (2006) examines the effects of nine human resources management practices on the components of organizational commitment, in two types of institutions in Holland: separatist and hegemonic. Their results indicate that some practices are correlated positively with commitment, but they differ according to the characteristics of the institutions considered. This supports the argument that the way these practices are configured should be suited to the organization's identity.

Meanwhile, according to Kelman (2006), people can be integrated into a social system, such as an organization, by adherence to the rules, by involvement with their roles, or even by the sharing of values. A study by Tamayo (2005), carried out in a public organization, confirms that values such as prestige, workers' well-being and autonomy have a positive relationship with the commitment of employees. While other values, which are also antecedents of commitment, are negatively associated, such as tradition and expertise. This indicates that in addition to the organizational factors listed above, managerial support, freedom at work, rewards, available time and uncertainties at work, there are other antecedents of commitment that can also have an influence.

\section{Internal marketing}

The involvement of employees, whom Whiteley (1996) denominates internal customers, is crucial for the implementation of plans that guide the organization to meet the customers' expectations. Marketing, previous focused directly on external customers, is nowadays also focused on internal customers, as a means of serving the first through the motivation of the second. Joseph (1996, p . 55) states that

[...] Internal Marketing is the management of human resources, allied theories, principles and techniques to motivate, mobilize and manage employees at all levels of the organization to continuously improve the way they serve external customers and each one. Effective internal marketing responds to the needs of employees, as well as promoting the organizational mission and goals.

For some authors (BERRY, 1981; GRÖNROOS, 1990a; BERRY; PARASURAMAN, 1992; RAFIQ; AHMED, 1993; FOREMAN; MONEY, 1995; NICKLES; WOOD, 1999; VASCONCELOS, 2004; and PIZZINATTO et al.,2005) internal marketing is a philosophy practiced by the organization that sees the employee as an internal customer.

However, the majority of concepts are related to a more generalized aspect of internal marketing, i.e. a perspective of joint work between internal and external marketing, seeking, in this way, to satisfy the external customer. In other words, it is a managerial philosophy that is aimed at efficient performance in the company's external environment, through an appropriate work environment that respects the wishes and needs of the employees (PIERCY; MORGAN, 1991; RAFIQ; AHMED, 1993; FOREMAN; MONEY, 1995; VAREY, 1995; PIERCY, 1995; CAHILL, 1995, VAREY; LEWIS, 1999; GILMORE, 2000; AHMED; RAFIQ, 2002; RAFIQ; SAAD, 2003; NAUDÉ; DESAI; MURPHY, 2003; LINGS, 2004; FIGUEIREDO NETO; MACHADO; SILVA, 2010).

Organizations must be prepared to learn to interpret each client and offer them the benefits, security and reliability that the product or service provides. They also need strategies to defend themselves against competition aimed at attracting and seducing the customer by offering even greater advantages 
(KOTLER, 2003). Thus, many companies opt for internal marketing as a tactic for training and motivating their employees, always seeking to optimize the results.

Cerqueira (1994) views internal marketing as projects and actions that an organization must undertake to consolidate the cultural basis of the commitment of its employees, such as adequate development of their various technologies. The purpose of these projects, according to the author, is to improve the relationship and communication, and determine a motivational basis for the commitment between people and their commitment to the organizational system. Beatty, Suh and Yoon (2000) emphasize that within the perspective of internal marketing, if the service of the company wants its employees to carry out a good work, it needs to prepare to carry out an equivalent work with its employees.

In the same line of thought, Ahmed and Rafiq (2002, p. 10) argue that "internal marketing consists of a planned effort, using a typical marketing vision aimed at motivating employees to implement and integrate organizational strategies geared towards guiding the customer". Kotler (2003) states that recent studies on management have sought to demonstrate that communication between employees, involvement and commitment, redesigned business processes, perceived relations between employees, and customer satisfaction are predominant. The author also emphasizes that the area of marketing can take responsibility for all communication on the product or service; however, if the internal structure does not match the image transmitted by the company, the marketing effort will be compromised.

Internal marketing, according to Vasconcellos (2004), overlaps with both human resources and marketing, a fact that strategically facilitates synergy. This area, says the author, should be integrated with the others, because the greater the integration, the higher the chances of success in serving external customers. Pizzinatto et al. (2005) add to this, affirming that internal marketing is the application of human resources, techniques, theories and relevant principles in order to motivate, promote cooperation and manage employees of all levels of the organization towards continuous improvement in the way in which they serve external customers and the way they treat them.

The operationalization of internal marketing, according to Ahmed and Rafiq (2002), requires specific attitudes of business leaders, notably:

a) Acceptance of the philosophy and technique of marketing;

b) Customer- and market-focus;

c) A participatory Approach that reaches all hierarchical levels;

d) Strategic Focus for the management of human resources, in order to ensure alignment of the human resources strategy with the strategy of the organization; and,

e) Coordination of all the managerial activities for the achievement of customer-focus, or market-focus, or even management with focus on the client/market.

Thus, it is understood that internal marketing constitutes professional organizations with behavior that is effectively customer-focused and leads to the development of strategies by viewing employees as internal customers, whose expectations must also be met.

\section{Procedimentos metodológicos}

The data of this survey (BABBIE, 2003) were obtained from a hundred and twenty-six self-administered questionnaires applied in situ and also received by electronic mail. The data collection tool was organized in three blocks, and general data was also gathered from the respondents. The questions included the institution where the respondent works, the date they joined the institution, their weekly workload, whether they teach at another institution, whether they exercise professional activity outside of teaching, and their sex.

The first category gathered data on organizational factors, according to the model of Moriano et al. (2009). By means of five statements, five variables were recorded, namely: managerial support (AD), freedom at 
work (LT), rewards (RC), available time (TD), and uncertainty in tasks (IT). The next block contained eighteen items relating to the teachers' organizational commitment, measuring their affective (CA), continuance (IC) and normative (CN) components based on six items for each one. It was drawn up based on model of Meyer and Allen (1991), validated for Brazil by Medeiros and Enders (1998) and recently applied to university teachers in the studies of Giacomassa (2013) and Lizote (2013).

The third block gathered data on the teachers' perceptions concerning some aspects of internal marketing that is developed at their institution. To record these perceptions, twenty-one items, suggested by Bohnenberger (2005), were adapted to the university environment. These items were distributed as follows: four in the category development (D), another four relating to admission and responsibilities of contracted parties (AR), four more to determine adequacy to their functions (AF), six to measure internal communication (CIn) and three to measure external communication (EC). A five-point Likert-type scale was used in the three blocks, with 1 representing "Strongly Disagree" and 5 "totally agree".

The questionnaire also included a statement that summarizes the general perception of the interviewees about how they think they are seen within the institution (PG). The alternative responses were: (i) an inversion in the medium and long term; (ii) a cost to decrease; (iii) a customer of the university; (iv) a human being; and, v) a resource that is difficult to administer. This categorical variable allowed the database to be selected, and analyses to be carried out according to this aspect, which the work of Bohnenberger (2005) calls "Philosophy of Management".

All the completed questionnaires were organized in an Excel® electronic spreadsheet, with preprocessing of the data (HAIR Jr. et al., 2009). We identified fifteen items of missing data, eleven in the block of organizational factors and four in commitment. One teacher failed to respond to two items, while the other missing data were from just one teacher. As thus quantity is very small in relation to the permitted maximum, and as the missing data was not associated with an pattern, it was decided to fill in the empty cells with the mean values for the corresponding indicators. Outliers were assessed through the Box Plots graphics function of the Statistica software ${ }^{\circledR}$, using a coefficient of 1.5 deviations. One hundred and sixty-two (162) outliers were detected, representing approximately $1.5 \%$ of the data collected. After checking that they were distributed among the various respondents and items, it was decided to keep them in the database. No typing errors were found.

In order to evaluate the normality of distribution of the variables, considering that the data came from Likert scales, calculations of asymmetry and kurtosis performed (HAIR, Jr.) et al., 2009). Finney and DiStefano (2006) affirm that data with coefficients of up to 2 for asymmetry and up to 7 for kurtosis, in module, can be considered almost normal. It was confirmed that no value exceeded those limits and, as a result of the procedures described, all 126 questionnaires and 65 variables were kept in the final database.

The statistical methods used were exploratory factor analysis (EFA) and confirmatory factor analysis (CFA), Analysis of variance (ANOVA) and analysis of correlations. For each method, the premises of their use were evaluated (HAIR Jr. et al., 2009). Before performing the factorial analyses, Cronbach's alpha coefficient was calculated for each dimension or component of the construct considered, and the correlation of the item with the total, according to the procedure suggested by Churchill Jr. (1979). Subsequently, the test of Kaiser, Olkin and Meyer was used, and that of Bartlett to confirm the feasibility of using factorial analysis. In the EFA, extraction of the principal components was used, which requires no multi-normalidade, the factors being extracted according to the criterion of Kaiser, based on matrices of correlations. Other restrictions used were factor loadings had to be equal to or higher than 0.70 in module and the commonality equal to or higher than 0.5 . The variance extracted by the factor in the case of single-dimensionality had to be equal or greater than $50 \%$. In the CFA, a criteria of coefficient between the indicators and the dimension or construct considered equal to or greater than 0.5 was used. Based on the factors formed with the indicators that met the minimums stipulated to be retained, factorial scores were generated for the respondents, which were used in subsequent processes. The ANOVAs performed 
were always univariate and, therefore always very robust forward violations of normality and homoscedasticity (HARRIS, 1975), which is generally the case when using Likert scales.

\section{Apresentação e análise dos resultados}

With each dimension of the organizational factors, item-total correlation was done, and the reliability was calculated with Cronbach's alpha, as suggested by Churchill Jr. (1979). The results indicated that the factor time available (TD) was the only one with item-total correlation values lower than 0.4. This occurred with three of the five indicators. In addition, the Cronbach's alpha calculated for this dimension was also far below the recommended value of 0.7 , reaching only 0.3539 . As a result, it was decided to exclude this organizational factor from the subsequent analyses.

The exploratory factorial analyses performed individually with each one of the dimensions, and in accordance with the restrictions described in the methodological procedures, resulted in the exclusion of some items. Next, a confirmatory factor analysis was carried out, which helped define the final items for each dimension. Finally, a new factorial analysis was performed for the construct with all the selected indicators. Using the criterion of Kaiser, four factors were extracted which, after normalized varimax rotation, resulted in the association of each factor with one of the dimensions, as shown in Table 1.

Table 1 - Organizational Factors. Factors extracted by principal components and normalized varimax rotation. Values of less than $0.3\left(^{*}\right)$.

\begin{tabular}{c|c|c|c|c}
\hline & Factor 1 & Factor 2 & Factor 3 & Factor 4 \\
\hline AD1 & $*$ & $*$ & 0.754010 & $*$ \\
\hline AD3 & $*$ & $*$ & 0.853132 & $*$ \\
\hline AD4 & $*$ & $*$ & 0.729004 & $*$ \\
\hline AD5 & $*$ & $*$ & 0.761943 & $*$ \\
\hline LT3 & $*$ & 0.779011 & $*$ & $*$ \\
\hline LT4 & $*$ & 0.855836 & $*$ & $*$ \\
\hline LT5 & $*$ & 0.881695 & $*$ & $*$ \\
\hline RC2 & $*$ & $*$ & $*$ & 0.823928 \\
\hline RC3 & $*$ & $*$ & $*$ & 0.877890 \\
\hline RC4 & $*$ & $*$ & $*$ & 0.852542 \\
\hline RC5 & $*$ & $*$ & $*$ & 0.797252 \\
\hline IT1 & 0.753610 & $*$ & $*$ & $*$ \\
\hline IT3 & 0.703340 & $*$ & $*$ & $*$ \\
\hline IT4 & 0.833333 & $*$ & $*$ & $*$ \\
\hline IT5 & 0.701881 & $*$ & $*$ & $*$ \\
\hline Expl.Var & 2.601792 & 2.281317 & 2.755182 & 3.221841 \\
\hline Prp.Tot1 & 0.173453 & 0.152088 & 0.183679 & 0.214789 \\
\hline
\end{tabular}

Source: Research data.

Based on this configuration, the factorial scores were generated by associating each him with the corresponding dimension. The first factor with the uncertainty in tasks, the second with freedom at work, the third with managerial support, and the fourth with rewards. The data for commitment were then analyzed in the same way, resulting in the figures shown in Table 2.

Table 2 - Organizational Commitment. Factors extracted by principal components and normalized varimax rotation. Values of less than $0.3(*)$. 


\begin{tabular}{c|c|c|c}
\hline & Factor 1 & Factor 2 & Factor 3 \\
\hline CA1 & 0.711672 & $*$ & $*$ \\
\hline CA2 & 0.816782 & $*$ & $*$ \\
\hline CA3 & 0.801680 & $*$ & $*$ \\
\hline CA4 & 0.926919 & $*$ & $*$ \\
\hline CA6 & 0.936561 & $*$ & $*$ \\
\hline CI2 & 0.856488 & $*$ & $*$ \\
\hline CI3 & $*$ & -0.834207 & $*$ \\
\hline CI4 & $*$ & -0.834200 & $*$ \\
\hline CI5 & $*$ & -0.733563 & $*$ \\
\hline CI6 & $*$ & -0.814014 & $* .869003$ \\
\hline CN2 & $*$ & $*$ & 0.867556 \\
\hline CN3 & $*$ & $*$ & 0.804236 \\
\hline CN5 & $*$ & $*$ & 0.730783 \\
\hline CN6 & $*$ & $*$ & 2.994321 \\
\hline Expl.Var & 4.714366 & 3.195863 & 0.199621 \\
\hline Prp.Tot1 & 0.314291 & 0.213058 & 0
\end{tabular}

Source: Research data.

In the same way as for the organizational factors, with the results obtained for the components of commitment, the factorial scores of the respondents were generated. The first factor relative to the affective component, the second to the continuance, and the third to the normative.

Next, the data on internal marketing were analyzed, using the same procedures. The difference with the previous results is that the five aspects considered do not constitute dimensions that reflect a single construct, therefore it was decided to analyze them independently. The items considered for each aspect are shown in Table 3.

Table 3 - Aspects of internal marketing. D: development; AR: admission and Responsibilities; AF: suitability to functions; CIn: internal communication; and, CE: external communication.

\begin{tabular}{c|c}
\hline \multicolumn{2}{c}{ Factor 1 } \\
\hline D2 & 0.715770 \\
\hline D3 & 0.728464 \\
\hline D4 & 0.733964 \\
\hline Expl.Var & 1.581690 \\
\hline Prp.Totl & 0.527230 \\
\hline
\end{tabular} \begin{tabular}{c|c} 
AR1 & 0.757711 \\
\hline AR2 & 0.820601 \\
\hline AR3 & 0.756803 \\
\hline Expl.Var & 1.820263 \\
\hline Prp.Totl & 0.606754 \\
\hline
\end{tabular}

\begin{tabular}{c|c}
\hline \multicolumn{2}{c}{ Factor 1 } \\
\hline AF1 & 0.811335 \\
\hline AF2 & 0.748206 \\
\hline AF4 & 0.804928 \\
\hline Expl.Var & 1.865986 \\
\hline Prp.Totl & 0.621995 \\
\hline
\end{tabular}

\begin{tabular}{c|c}
\hline \multicolumn{2}{c}{ Factor 1 } \\
\hline CIn3 & 0.807480 \\
\hline CIn4 & 0.822064 \\
\hline CIn5 & 0.893405 \\
\hline Expl.Var & 2.125986 \\
\hline Prp.Totl & 0.708662 \\
\hline
\end{tabular}

\begin{tabular}{c|c}
\hline \multicolumn{2}{c}{ Factor 1 } \\
\hline CE1 & 0.717963 \\
\hline CE2 & 0.845139 \\
\hline CE3 & 0.882785 \\
\hline Expl.Var & 2.009040 \\
\hline Prp.Totl & 0.669680 \\
\hline
\end{tabular}

Source: Research data.

For each of these aspects, the factorial scores were generated for the teachers who took part in the research and together with those related to the organizational factors and to commitment, a new database was created. The item corresponding to the general perception (PG) that the teacher believes the institution has of him or her was also included in it.

Based on this new data matrix, the correlations of the organizational factors and aspects of the internal marketing with the components of commitment were also calculated. The results showed that in the case of marketing, only internal development had a significant and positive correlation with the normative component of commitment. The analysis of correlations of the organizational factors show that the affective component has a significant and positive association with managerial support, rewards and uncertainty at work, the normative component with managerial support and rewards, and the continuance component with freedom in the workplace, but with a negative correlation. 
Considering that this result with the total set of teachers can be derived from the heterogeneity of the respondents, the answer was sought using the categorical variable PG (general perception). Using this as a predictor of ANOVA, it was demonstrated that for the various aspects of internal marketing only, the simultaneous comparisons showed significance. When paired comparisons were carried out using the Tukey test for an unequal number of repetitions, it was found that the groups identified as "a cost to decrease" and "a resource that is difficult to administer" generally had lower average values than the other groups. Thus, the correlations between organizational factors and internal marketing were compared with the components of commitment for each of the groups derived from this variable.

For the first group, when the teachers thought they were seen seen by the institution as "inversion in the medium or long term" there is only a significant and negative correlation between the affective component of commitment and uncertainty at work, i.e. when the organizational limitations decreased, affective commitment decreased, and vice-versa. With the aspects investigated from internal marketing, on the other hand, significant and positive correlations were found between the affective component and communication, both internal and external. There was also a significant association between external communication and the normative component. The second group, "a cost to decrease", shows that affective commitment is positively correlated with uncertainty in tasks of organizational factors, but with none of the aspects of internal marketing.

The third group, those who believe they are seen as a "customer of the university", showed a significant and positive relationship between the normative component of commitment and rewards, but for all aspects of marketing, the correlations of admission and responsibilities (AR) occur with the affective (CA) and normative (CN) components. CA, in turn, was correlated with AF "adaptation to the functions" and $\mathrm{CN}$ with CIn "internal communication". The fourth and largest group that represents those who think they are seen as "human beings" in the institution, a group with fifty-eight members, showed significant positive correlations for affective commitment with managerial support and rewards. It also showed significant, but negative correlations between the continuance component and rewards and freedom at work, indicating that the continuance component decreases as freedom and rewards increase. For internal marketing, only the normative component had positive and significant correlations with development, admission and responsibility, and with suitability for functions.

Finally, the fifth group, comprising those who think that the institution considers them as "a resource that is difficult to administer", had no significant correlations with the aspects of internal marketing. However, with the organizational factors, it is confirmed that there are significant positive correlations for the affective component of commitment and the factors managerial support, rewards, and uncertainty at work, the latter two factors also being associated positively and significantly with the normative component.

\section{Considerações finais}

Because the database is heterogeneous, as it includes teachers of public, private community and private profit-making universities, with different labor contracts, it would not be not appropriate to analyze the associations of organizational factors with commitment as though it were the responsibility of human resources management alone, but rather, as a representative set of actions is carried out by the upper management. The five aspects listed; managerial support, freedom at work, rewards, available time and uncertainties at work, were recognized by the respondents as actions that are developed by their institutions. However, it was necessary to exclude the dimension "time available" due to a lack of correlation between the indicators used to measure this dimension. The other four aspects together form the construct denominated organizational factors which, rotating the result of factorial analysis, leads to

a relative independence between the dimensions and enables the use of factorial scores to calculate correlations with the components of commitment. 
The relationships found with significance among the organizational factors and the three components of commitment were consistent with those recorded in other studies. Thus, managerial support had a positive and significant correlation with the affective component of commitment, as verified in the metaanalysis of Rhoades and Eisenberger (2002), which describes a strong positive relationship between affective commitment and organizational support perceived by the employee. This same association has been reported for workers in various cultures, including Korea (LEE; PECCEI, 2006), China (LIU, 2009) and India (GOKUL; SRIDEVI; SRINIVASAN, 2012). Regarding the association between the affective component and rewards, the result also corroborates the findings of other studies, such as those of Burke (2002), Kuvaas (2006) and Malhotra, Budhwar and Prowse (2007), who report the existence of significant positive relationships. For the dimension of uncertainty at work, which represents the organizational limitations perceived by the employee, no previous results were found, and the positive link that exists with affective commitment was unexpected, based on the theoretical construct.

The relationship of the normative component with managerial support was the same as for the affective component, i.e. significant and positive. This result has been reported in several studies, such as those of Battistelli, Mariani and Bello (2006) and those of Aube, Rousseau and Morin (2007), among others. This relationship can be explained based on the rules of reciprocity. Thus, an employee who receives support or favorable attitudes feels obliged to reciprocate what he or she has received. Rewards, in turn, also had a positive and significant association with the normative component of commitment, as reported in a study by Malhotra, APJ et al . (2007) relating to intrinsic rewards. Finally, instrument or calculative commitment showed a negative and significant correlation with freedom at work, which shows that the more the teacher feels they have freedom to carry out their work, the more the calculative component decreases. This is in line with the understanding inherent to this kind of commitment, which relates to the psychological state of need, of having to stay in the organization.

Considering the aspects of internal marketing that were analyzed individually, it is seen that only normative component had a positive and significant association with development. This result is consistent, in part, with the study of Meyer, Irving and Allen (1998), as their findings on the actions that include the development show a positive relationship with the normative component and also with the affective component. It still has a negative correlation with the continuance component. However, these results obtained with the complete database change noticeably when the analyses are carried out based on the groups that are distinguished by the so-called general perception question. It identifies the teachers by the idea of how they imagine being considered by the organization.

In the analyses by groups, in three of them, distinct aspects of internal marketing showed a correlation with commitment. However, in no case did this occur for the continuance component. Internal communication presents a positive association with the affective component, in the first group, and the normative component, in the first and third groups, corroborating the study of Bohnenberger (2001), which also found a weak but positive relationship with the continuance component. Admission and responsibility (AR) and suitability for functions (AF), in turn, showed a correlation with the affective and normative components in the third and fourth groups. This relationship was also verified by Bohnenberger (2005), however in that study, these aspects were considered together as human resources practices. Finally, the development showed a correlation with the normative component of commitment for the fourth group, and since it was the largest, it had the biggest influence.

Studies of this nature contribute to the study area by showing that in organizations, the internal customer marketing process requires skilled, committed and motivated employees to serve customers. The prioritization of human skills by entities is the recognition that human capital is a decisive factor in a competitive environment. Therefore, in order for the employees' commitment to external customer satisfaction to occur, it is necessary to count on motivated people in the organization, feeling important to the company and, consequently, with positive performance, since it is the human asset of the organization that coexists with the setbacks of day to day business. The degree of organizational 
commitment of employees has long been recognized as a fundamental element to achieve better performance and success of the entity. (WEYMER et al., 2018).

It is understood, therefore, that in order to thrive or survive in the context of major changes in the business environment, organizations must adopt entrepreneurial management, promoting freedom of action, providing available time and rewards to employees with the support of management. In this sense, proactive companies are already moving in this direction, with decentralization being incorporated into strategic planning, aiming at reducing operational costs and raising the quality of the products / services offered.

Various limitations of this study should be taken into account. Firstly, it should be noted that the sample is based on a specific country, Brazil, and a particular system of higher education. This could influence some of the relations found, due to cultural differences and differences in educational systems in different countries. Secondly, in this study we investigated only one type of higher education institution universities, therefore there may be limitations when extrapolating these results to other types of institutions. Thirdly, the organizational factors and marketing aspects chosen might not have the same significance in public and private universities.

Further studies may clarify the relationships between the constructs considered. Many of the investigations that deal with them have been been conducted in other types of organizations and, therefore the results obtained in an educational context may be useful in future comparative studies. Another suggestion for future study is to examine these relationships, taking into consideration the legal nature of HEIs.

\section{Referências}

AHMED, P.; RAFIQ, M. Internal marketing: tools and concepts for customer-focused management. Oxford: Butterworth-Heinemann, 2002.

AHMED, P. K.; RAFIQ, M.; SAAD, N. M. Internal marketing and the mediating role of organizational competencies. European Journal of Marketing, v. 37, n. 9, p. 1221-1241, 2003.

AMARAL, N. A. Comprometimento organizacional e bem-estar subjetivo: um estudo com professores universitários. Dissertação (Mestrado em Psicologia), Universidade Federal da Bahia, 2008.

ANDRADE, A. R de. A gestão da universidade sob a ótica da teoria dos recursos e capacidades. In: Anais do XXX Encontro Nacional dos Programas de Pós-Graduação em Administração, 2006.

ANDRADE, A. R de. A universidade como organização complexa. Revisa de Negócios. Blumenau, v. 7, n. 3, p. 15-28, 2002.

AUBÉ, C.; ROUSSEAU, V.; MORIN, E. M. Perceived organizational support and organizational commitment: The moderating effect of locus of control and work autonomy. Journal of Managerial Psychology, v. 22, n. 5, p. 479-495, 2007.

BABBIE, E. Métodos de pesquisa de survey. Belo Horizonte: UFMG, 2003.

BANDEIRA, M. L.; MARQUES, A. L.; VEIGA, R. T. As dimensões múltiplas do comprometimento organizacional: um estudo na ECT/MG. Revista de Administração Contemporânea, v. 4, n. 2, p. 133$157,2000$.

BASTOS, A. V. B. \& BORGES-ANDRADE, J. E. Comprometimento com o trabalho: padrões em diferentes contextos organizacionais. Revista de Administração de Empresas, v. 42, n. 2, p. 31-41, 2002. 
BASTOS, A. V. B. Comprometimento organizacional: a estrutura dos vínculos do trabalhador com a organização, a carreira e o sindicato. Tese (Doutorado em Psicologia), Universidade de Brasília, Brasília, 1994.

BASTOS, A. V. B., LIRA, S. B. Comprometimento no trabalho: um estudo de caso em uma instituicão de serviços na área de saúde. Organizações e Sociedade, v. 4, n. 9, p.39-64, 1997.

BATTISTELLI, A.; MARIANI, M. BELLÒ, B. Normative commitment to the organization, support and self-competence. In: MINATI, G.; PESSA, E.; ABRAM, M. (Eds.) Systemics of Emergence: Research and Development. New York: Springer Science, p. 515-526, 2006.

BEATTY, S. E.; SUH, J.; YOON, M. H. The effect of work climate on critical employee and customer outcomes. International Journal of Service Industry Management, [S. 1.: s.n.], 2001.

BECKER, T. E.; KLEIN, H. J.; MEYER, J. P. Commitment in organizations: acumulated wisdon and new directions. In: BECKER, T. E.; KLEIN, H. J.; MEYER, J. P. (Eds.) Commitment in organizations: acumulated wisdon and new directions. New York: Routledge, Taylor and Francis Group, p. 419-452, 2009.

BERRY, L. L.; PARASURAMAN, A. Services marketing starts from within. Marketing Management, v. 1, n. 1, p. 24-34, 1992.

BERRY, L. L. The employee as customer. Journal of Retailing Banking, v. 3, n. 1, p.33-40, 1981.

BERTUCCI, J. L. Percepção ambiental e estratégias gerenciais em instituições de ensino superior: uma conexão improvável. In: Anais do XXIII Encontro Nacional dos Programas de Pós-Graduação em Administração, 1999.

BOHNENBERGER, M. C. Marketing interno: la actuación conjunta entre recursos humanos y marketing en busca del compromiso organizacional. Tesis (Doctorado en Economía de la Empresa), Universitat de les Illes Balears, 2005.

BOHNENBERGER, M. C. O marketing interno como ferramenta para elevar o comprometimento organizacional. Dissertação (Mestrado em Administração), Pontifícia Universidade Católica do Rio de Janeiro e Universidade do Vale do Rio dos Sinos, 2001.

BONAVIDES, R. O. P.; OLIVEIRA, J. A.; MEDEIROS, C. A. F. Comprometimento organizacional: um estudo das consequências do comprometimento para os trabalhadores. In: Anais do XXX Encontro Anual da Associação Nacional de Pós-Graduação em Administração, 2006.

BRANDÃO, M. G. A. Comprometimento organizacional na administração pública: um estudo de caso em uma instituição universitária. Dissertação (Mestrado em Administração), Universidade Federal da Bahia, 1991.

BUCK, J. M.; WATSON, J. L. Retaining Staff Employees: The relationship between human resources management strategies and organizational commitment. Innovative Higher Education, v. 26, n. 3, p. 175-193, 2002.

BURKE, W.W. Organizational change: theory and practice. Sage: Thousand Oaks, 2002.

CAHILL, D. J. The managerial implications of the learning organizations: a new tool for internal marketing. Journal of Services Marketing, v. 9, n. 4, p. 43-51, 1995.

CERQUEIRA, W. Endomarketing: educação e cultura para a sociedade. Rio Janeiro: Qualitymark, 1994. 
CHANG, J. Gestão de pessoas pelo desenvolvimento do comprometimento organizacional: uma abordagem holística e simultânea dos determinantes envolvidos no processo. Tese (Doutorado em Administração), Universidade de São Paulo, São Paulo, 2001.

CHAVES, T. A. Comprometimento organizacional: um estudo de caso em uma unidade do Centro Federal de Educação Tecnológica no interior de Minas Gerais. Dissertação (Mestrado em Administração), Faculdade Novos Horizontes, 2011.

CHEN, Z. X.; FRANCESCO; A. M. The relationship between the three components of commitment and employee performance in China. Journal of Vocational Behavior, v. 62, n. 3, p. 490-510, 2003.

CHURCHILL JR., G. A. A paradigm for developing better measures of marketing constructs. Journal of Marketing Research, v. 16, n. 1, p. 64-74, 1979.

COMMEIRAS, N.; FOURNIER, C. Critical evaluation of Porter et al.'s organizational commitment questionnaire: Implications for researchers. Journal of Personal Selling e Sales Management, v. 23, n. 3, p. 239-245, 2003.

COZZI, A. O.; ARRUDA, C. Desenvolvendo a capacidade empreendedora de uma organização. In: Anais do III Encontro de Estudos Organizacionais, Atibaia, 2004.

FIGUEIREDO NETO, A. L. V.; MACHADO, D. T. S.; SILVA, Y. P. M. O endomarketing como maximizador do capital humano e seus resultados nos objetivos finais da organização. Revista Científica do Itpac. v. 3, n. 4, 2010.

FINNEY, S. J.; DiSTEFANO, C. Non-normal and categorical data in structural equation modeling. In: HANCOK, G. R.; MUELEER, R. O. Structural equation modeling: a second course. Charlotte, NC: Information Age Publ., 2006.

FOREMAN, S. K.; MONEY, A. H. Internal marketing: concepts, measurement and application. Journal of Marketing Management, v. 11, p. 755-768, 1995.

GIACOMASSA, L. D. Comprometimento organizacional e transferência da aprendizagem em organizações: um estudo entre professores universitários. Tese (Doutorado em Psicologia), Universidade Federal de Santa Catarina, 2013.

GIAUQUE, D.; RESENTERRA, F.; SIGGEN, M. The relationship between HRM practices and organizational commitment of knowledge workers. Facts obtained from Swiss SMEs. Human Resource Development International, v. 13, n. 2, p. 185-205, 2010.

GILMORE, A. Managerial interactions of internal marketing. VAREY, R. J.; LEWIS, B. R. (eds.) Internal marketing: directions for management. London: Routledge, 2000.

GOKUL, A.; SRIDEVI, G.; SRINIVASAN, P. T. The relationship between perceived organizational support, work engagement and affective commitment. AMET International Journal of Management, v. 4, n.2, p. 29-37, 2012.

GONZÁLEZ, T. F.; GUILLÉN, M. Organizational commitment: a proposal for a wider ethical conceptualization of normative commitment. Journal of Business Ethics, v.78, n. 3, p. 401-414, 2008.

GRANT, A. M. Having yourself committed: Bridging Between Personal Projects and Organizational Commitment. (Unpublished report/2003). Cambridge, MA, United States, Harvard University.

GRÖNROSS, C. Relationship approach to marketing in service contexts: the marketing and organizational behavior interface. Journal of Business Research, v. 20, n. 1, p. 3-11, 1990. 
HAIR Jr., J. F.; BLACK, W. C.; BABIN, B. J.; ANDERSON, R. E.; TATHAM R. L. Análise multivariada de dados. 6 ed., Porto Alegre: Bookman, 2009.

HARRIS, G. E.; CAMERON, J. E. Multiple dimensions of organizational and commitment as predictors of turnover intentions and psychological well-being. Canadian Journal of Behavioral Science/Revue Canadienne des Sciences du Comportment, v. 37, n. 3, p. 159-169, 2005.

HARRIS, R. J. A primer of multivariate statistics. New York: Academic Press, 1975.

HASHIMOTO, M. Espírito empreendedor nas organizações: aumentando a competitividade através do intraempreendedorismo. São Paulo: Saraiva, 2006.

HASHIMOTO, M.; ANDREASSI, T.; ARTES, R.; NAKATA, L. E. Relações entre Intraempreendedorismo, Clima Organizacional e Desempenho financeiro - Um Estudo sobre as Melhores Empresas para se Trabalhar no Brasil. In: Anais do XXXIV Encontro Anual da Associação Nacional de Pós-Graduação em Administração, Rio de Janeiro, 2010.

HISRICH, R. D.; PERTERS, M. P. Empreendedorismo. 5. ed., Porto Alegre: Bookman, 2004.

HORNSBY, J. S.; KURATKO, D. F. Y.; ZAHRA, S. A. Middle manager's perception of the internal environment for corporate entrepreneur-ship: assessing a measurement scale. Journal of Business Venturing, v. 17, n. 1, p. 253-273, 2002.

IVERSON, R. D.; BUTTIGIEG, D. M. Affective, normative and continuance commitment: can the 'right kind' of commitment be managed? Journal of Management Studies, v. 36, n. 3, p. 307-329, 1999.

JOSEPH, W. Benoy. Internal marketing builds service quality. Marketing Health Services, [S.l.:s.n.], 1996.

KELMAN, H. C. Interest, relationships, identities: tree central issues for individuals and groups in negotiating their social environment. Annual Review of Psychology, v. 57, p. 1-26, 2006.

KOTLER, P. Administração de marketing: a edição do milênio. São Paulo: Prentice Hall, 2003.

KURATKO, D. F.; HODGETTS, R. M. Entrepreneurship: a contemporary approach. $4^{\text {th }}$ Ed., Orlando: The Dryden Press, cap. 1, p. 4-28 e cap. 2, p. 29-52, 1998.

KURATKO, D. F.; HORNSBY, J. S.; BISHOP, J. W. An examination of managers' entrepreneurial actions and job satisfaction. International Entrepreneurship and Management Journal, v. 1, n. 3, p. 275-291, 2005.

KURATKO, D. F; MONTAGNO, R. V.; HORNSBY, J. S. Developing an intrapreneurial assessment instrument for effective corporate entrepreneurial environment. Strategic Management Journal, v. 11 (Special Issue), p. 49-58, 1990.

KUVAAS, B. Work performance, affective commitment, and work motivation: the roles of pay administration and pay level. Journal of Organizational Behavior, v.27, n. 3, p. 365-385, 2006.

LEE, J.; PECCEI, R. (2007). Perceived organizational support and affective commitment: The mediating role of organization-based self-esteem in the context of job insecurity. Journal of Organizational Behavior, v. 28, n. 6, p. 661-685, 2007.

LINGS, I. N. Internal market orientation - construct and consequences. Journal of Business Research, v. 57, n. 4, p. 405-413, 2004.

LIU, Y. Perceived organizational support and expatriate organizational citizenship behavior. Personnel Review, v. 38, n. 3, p. 307-319, 2009. 
LIZOTE, S. A. Relação entre competências empreendedoras, comprometimento organizacional, comportamento intraempreendedor e desempenho em universidades. Tese (Doutorado em Administração e Turismo), Universidade do Vale do Itajá, 2013.

MALHOTRA, N.; BUDHWAR, P.; PROWSE, P. Linking rewards to commitment: An empirical investigation of four UK call centres. International Journal of Human Resource Management, v.18, n.12, p. 2095-2017, 2007.

MARRAS, J. P. Administração de recursos humanos: do operacional ao estratégico. $3^{\mathrm{a}}$ Ed., São Paulo: Futura, 2000.

McELROY, J. C. Managing workplace commitment by putting people first. Human Resource Management Review, v.11, n.1, p.327-335, 2001

MEDEIROS, C. A. F. Comprometimento organizacional, características pessoais e performance no trabalho: um estudo dos padrões de comprometimento organizacional. Dissertação (Mestrado em Administração), Universidade Federal do Rio Grande do Norte, 1997.

MEDEIROS, C. A. F; ENDERS, W. T. Validação do modelo de conceitualização de Três Componentes do comprometimento Organizacional Meyer e Allen (1991). Revista de Administração Contemporânea, v. 2, n. 3, p. 67-87, 1998.

MEYER, J. P. Commitment in a changing world of work. In: BECKER, T. E.; KLEIN, H. J.; MEYER, J. P. (Eds.) Commitment in organizations: acumulated wisdon and new directions. New York: Routledge, Taylor and Francis Group, p. 37-68, 2009.

MEYER, J. P.; ALLEN, N. J. A three-component conceptualization of organizational commitment. Human Resource Management Review, v 1, p. 61-89, 1991.

MEYER, J. P.; ALLEN, N. J. Commitment in the workplace: theory, research and application. Advanced topics in organizational Behavior. SAGE Publications. Thousand Oaks, California, 1997.

MEYER, J. P.; ALLEN, N. J.; TOPOLNYTSKY L. Commitment in a changing world of work. Canadian journal of experimental Psychology, v. 39, n. 1/2, p. 83-93, 1998.

MEYER, J. P.; HERSCOVITCH, L. Commitment in the workplace: Toward a general model. Human Resource Management Review, v. 11, p. 299-326, 2001.

MEYER, J. P.; IRVING, P. G.; ALLEN, N. J. Examination of the combined effects of work values and early experiences on organizational commitment. Journal of Organizational Behavior, v. 19, n. 1, p. 29-52, 1998.

MORIANO, J. A.; TOPA, G.; VALEOR, E.; LÉVY, J. P. Identificación organizacional y conducta “intraempreendedora”. Anales de Psicología, v. 25, n. 2, p. 277-287, 2009.

MORROW, P. C.; McELROY, J.C. Work Commitment Conceptual and methodological developments for the management of human resources. Human Resource Management Review, v.11, n.1, p.177180,2001

MUNIZ, M. D. Educação superior em Santa Catarina: consolidação e expansão. Tese (Doutorado em Engenharia de Produção), Universidade Federal de Santa Catarina, 2006.

NAMASIVAYAM, K.; ZHAO, X. An investigation of the moderating effects of organizational commitment on the relationships between work-family conflict and job satisfaction among hospitality employees in India. Tourism Management, v. 28, p. 1212-1223, 2007. 
NAUDÉ, P.; DESAI, J.; MURPHY, J. Identifying the determinants of internal marketing orientation. European Journal of Marketing, v. 37, n. 9, p. 1205, 2003.

NICKELS, W. G.; WOOD, M. B. Marketing: relacionamentos, qualidade e valor. Rio de Janeiro: LTC, 1999.

PIERCY, N. F. Customer satisfaction and the internal market: marketing our customers to our employess. Journal of Marketing Practice: Applied Marketing Science, v. 1, p. 1355-2538, 1995.

PIERCY, N. F.; MORGAN, N. Internal marketing -the missing half of the marketing programme. Long Range Planning, v. 24, n. 2, p. 82-83, 1991.

PIZZINATTO, A. K.; PIZZINATTO, N. K.; GIULIANE, A. C.; PIZZINATTOO, N. K. marketing interno e cultura organizacional: um estudo de caso em empresa de multimarcas. Revista de Administração Mackenzie, v. 6, n. 1, 2005, p. 79-105, 2005.

POWELL, D. M.; MEYER, J. P. Side-bet theory and the three component model of organizational commitment. Journal of Vocational Behavior, v. 65, p. 157-177, 2004.

RAFIQ, M.; AHMED, P. K. The scope of internal marketing: defining the boundary between marketing and human resource management. Journal of Marketing Management, v. 9, p.219-232, 1993.

REGO, A.; CUNHA, M. P.; SOUTO, S. Espiritualidade nas organizações e comprometimento organizacional. Revista de Administração de Empresas-electrônica, v. 6, n. 2, 2007.

REGO, A.; SOUTO, S. A percepção de justiça como antecedente do comprometimento organizacional: um estudo luso-brasileiro. Revista de Administração Contemporânea, v. 8, n. 1, p. 151-177, 2004.

RHOADES, L.; EISENBERGER, R. (2002). Perceived organizational support: a review of the literature. Journal of Applied Psychology, v. 87, n.4, p. 698-714, 2002.

SANCHES, E. N. Organização e carreira: padrões de comprometimento de docentes universitários e a relação com o desempenho no ensino. Tese (Doutorado em Engenharia de Produção), Universidade Federal de Santa Catarina, 2004.

SHEN, J. HRM in chinese privately owned enterprises. Thunderbird International Business Review, v. 52, n. 2, p. 91-104, 2008.

SHEN, J.; ZHU, C. J. Effects of socially responsible human resource management on employee organizational commitment. The International Journal of Human Resource Management, v. 22, n. 15, p. 3020-3035, 2011.

SILVA, O. L. da; NUNES, S. C.; ANDRADE, D. F. Estilo do líder e comprometimento dos liderados: associando construtos em busca de possíveis relações. Revista Brasileira de Gestão de Negócios, v. 21, n. 2, p. 291-311, 2019

SIQUEIRA, M. M. M.; GOMIDE Jr., S. Vínculos do indivíduo com o trabalho e com a organização. In: ZANELLI, J. C. et al. Psicologia, organizações e trabalho no Brasil. Porto Alegre: ArtMed, 2004.

SMEENK, S.G.A.; EISINGA, R.N.; TEELKEN, J.C.; DOOREWAARD, J.A.C.M. The effects of HRM practices and antecedents on organizational commitment among university employees. The International Journal of Human Resource Management, v. 17, n. 12, p. 2035-2054, 2006.

STEVENSON, H. H.; JARILLO, J. C. A paradigm of entrepreneurship: entrepreneurial management. Strategic Management Journal, v. 11, p. 17-27, 1990. 
SU, S.; BAIRD, K.; BLAIR, B. Employee organizational commitment: the influence of cultural and organizational factors in the Australian manufacturing industry. The International Journal of Human Resource Management, v. 20, n. 12, p. 2494-2516, 2009.

TAMAYO, A. Valores organizacionais e comprometimento afetivo. RAM. Revista de Administração Mackenzie, v. 6, n. 3, p. 192-213, 2005.

VAREY, R. J. Internal marketing: a review and some interdisciplinar research challenges. Internacional Journal of Service Industry Management, v. 6, n. 1, 1995.

VAREY, R. J.; LEWIS, B. A Broadened conception of internal marketing. European Journal of Marketing, v. 33, n. 9, p. 937, 1999.

VASCONCELLOS, A. F. Processos de trocas intra-organizacionais: atualizando o conceito de marketing interno. Caderno de Pesquisas em Administração, [S. 1.: s.n.], 2004.

VITAL, M. S. Comprometimento organizacional: o caso dos professores substitutos da Universidade do Amazonas. Dissertação (Mestrado em Administração), Universidade Federal de Santa Catarina, 2002.

WEYMER, A. S. Q.; SCHUBER, K. J.; ESKENAZI, A. S.; MARTINS, P. A, de L. A contribuição de mulheres líderes no nível de comprometimento organizacional. Revista Gestão Organizacional, v. 11, n. 3, p. 76-91, 2018.

WHITELEY. R. A empresa totalmente voltada para o cliente. Rio de Janeiro: Campus, 1996.

ZAHRA, S.; KORRI, J. S.; YU, J. Cognition and international entrepreneurship: implications for research on international opportunity recognition and exploitation. International Business Review, v. 14, p. 129-146, 2005.

WEYMER, A. S. Q.; SCHUBER, K. J.; ESKENAZI, A. S.; MARTINS, P. A, de L. A contribuição de mulheres líderes no nível de comprometimento organizacional. Revista Gestão Organizacional, v. 11, n. 3, p. 76-91, 2018. 